\title{
Environmental Protest in the Czech Republic: Three Stages of Post-Communist Development ${ }^{*}$
}

\author{
ADAM FAGIN ${ }^{* *}$ \\ University of London, London, UK
}

\begin{abstract}
The role played by environmental activists in the events leading to the collapse of communist rule in Czechoslovakia has been well documented. With the old order swept aside and a liberal democratic constitutional framework rapidly established, it might be assumed that the environmental movement would have progressed painlessly from clandestine opposition to political prominence. However, for the nascent environmental movement, the post-communist decade has not seen a linear progression towards greater access and political efficacy. Though certain Prague-based organisations are currently enjoying a degree of relative influence within a renewed policy process, the movement was politically isolated and starved of resources throughout the Klaus period, thereby delaying their development. It is only now, more than a decade since the onset of democratic reform that environmental organisations are beginning to resemble their western counterparts. Even so, the resource issue remains a critical constraint and is tied to more fundamental problems relating to the development of civil society which directly impact upon the environmental movement at a time when critical decisions are being taken regarding nuclear energy and transport policy.
\end{abstract}

Czech Sociological Review, 2000 Vol. 8 (No. 2: 139-156)

\section{Introduction}

Environmental protest in the Czech Republic ${ }^{1}$ has changed quite considerably over the past decade. ${ }^{2}$ In terms of the political influence and capacity of environmental NGOs, there has not been a linear progression towards increased efficacy and pluralisation. Rather, it is possible to discern three distinct stages: an initial phase of political prominence and apparent radicalism (1990 - mid-1991); a period of political marginalisation and de-radicalisation (mid-1991 - 1996); and the current phase (1996 onwards) in which a cluster of large professional environmental NGOs have regained a degree of influence within a more open and consensual political opportunity structure. In trying to explain such variation in the nature and efficacy of environmental protest in the Czech Republic, a number of determinants can be identified. The political opportunity structure in which

\footnotetext{
*) Paper presented for the Workshop on "Environmental Protest in Comparative Perspective" at the 27th Joint Sessions of ECPR Workshops in Mannheim, 26-31 March, 1999.

**) Direct all correspondence to: Dr Adam Fagin, Department of Politics, Queen Mary and Westfield College, University of London, Mile End Road, London, E1 4NS, UK.

1) 'The Czech Republic' is used to cover the period after 1993, though the information up until the demise of the federation obviously relates to Czechoslovakia as a whole.

2) I would like to acknowledge the help of Hana Pernicová, formally Executive Director of Greenpeace $\breve{C}$, who has during lengthy interviews provided me with information and data on development in the environmental NGO sector over the past five years. I would also like to acknowledge the particular help of Dan Vondrouš (Duha), Jindřich Petrlík (Děti Země), Prof. Bedřich Moldan (ČSOP), Marie Hasiová and Zuzana Drhová (Zelený Kruh).
} 
NGOs operate is widely acknowledged to be a critical determinant of influence [Kriesi et al. 1995]. In the Czech case the political context has certainly fluctuated since the early 1990s and, as demonstrated in the discussion below, this has clearly had an impact on the capacity of the environmental movement. However, it is the lack of resources available to NGOs which has had the most profound impact on their capacity to gain political influence. Despite recent political changes that have ushered in a more consensual and noncombative arena for NGOs, their political capacity remains constrained by the absence of resources and a developed civil society capable of nurturing and resourcing associational activity. This is largely due to the legacy of four decades of soviet-style communism plus the political, social and economic turbulence of the ensuing transition process which in conjunction constitute a unique context in which fledgling NGOs are to operate.

Various theoretical approaches to the study of social protest, used in conjunction, offer a set of analytical tools for considering aspects of environmental protest in the Czech Republic since the end of the 1980s [Della Porta and Diani 1999, ch. 1]. The role of environmental groups as a catch-all political opposition during the final months of the communist regime seems to lend credence to the structuralist-functionalist school, which depicts social movements as a conglomeration of the dispossessed and marginalised in a rapidly changing, crisis-ridden system [Smelser 1962]. The role of clandestine environmentalists engaging in confrontational protest against the state during the 1980s, then gaining political influence and, in some cases, power after the revolution appears to endorse a life-cycle trajectory whereby all social movements pass through radical confrontational opposition to a phase of de-radicalisation in response to accommodation with the political elite [Offe 1990]. Indeed, the involvement of certain environmental NGOs in drafting new anti-pollution legislation immediately after the revolution, plus the gradual change in organisational structures and strategies suggests a more micro analytical approach based on resource availability and rational choice as a means of understanding the development of the environmental movement [Zald and McCarthy 1987].

However, the appropriateness of the various theoretical interpretations to the Czech case is somewhat superficial. Analysis of environmental protest cannot be extrapolated from the wider context of democratic consolidation. It is important, particularly with regard to the cyclic trajectory, to resist deterministic and reductionist interpretations regarding the eventual course of environmental protest. There has not been a linear progression whereby environmental NGOs have moved from a radical opposition movement to political inclusion within the new democratic political system. In fact, the fledgling environmental NGOs that emerged after the revolution lacked the experience, resources and cohesion to use the new political opportunity structure that was briefly made available to them. Moreover, the brief period of political inclusion after the revolution was eclipsed by a period of reactionary hostility, and within the space of three years the environmental movement found itself as excluded as it had been during the communist era. Although the period of flagrant hostility between the environmental movement and the government came to an end with the replacement of František Benda as minister of the environment after the 1996 election, and the relationship has subsequently improved quite considerably, to suggest that by virtue of having regained a measure of political influence the environmental movement has now completed the 'cycle' ignores the host of constraints that continue to limit their political capacity.

To analyse the development of the environmental movement in the Czech Republic from the perspective of strategies and patterns of protest in Western Europe can serve to 140 
misrepresent the post-communist political context and obscure a number of quite critical and specific constraints. For example, in the aftermath of the Velvet Revolution the recently 'liberated' environmentalists appeared to be rejecting conventional pressure group activity in favour of strategies and organisational forms characterised by western social scientists as a new form of social protest [Melucci 1985; Eder 1985; Dalton, Kuechler and Burklin 1990; Touraine 1981, 1988]. However, such radical tactics and approaches were more a reflection of environmental protest having emerged within the authoritarian political setting of communist rule and of young activists lacking any political experience than an outright rejection of more conventional forms of protest and organisation. Similarly the abandonment of radicalism and the emergence of more conventional lobbybased strategies after 1992 was not, as might be assumed, a sign that environmental NGOs had gained greater access or inclusion within the policy process. Indeed, despite adopting less confrontational and more conciliatory tactics, NGOs were being squeezed out of the political fray at this time due to the absence of resources and the lack of any political patronage. The former dissidents had virtually all left formal politics, and the fragmented opposition seemed largely disinterested in the environmental issue.

What will become evident from the analysis of environmental protest in the Czech Republic over the past decade is that while the relationship between the environmental sector and the political elite has certainly been important in determining strategy choice and influence, the issue of resources and the broader context of establishing civil society is paramount in terms of analysing the capacity of the environmental movement.

\section{9-1991: A Halcyon Era of Political Inclusion?}

In the months prior to the Velvet Revolution the number of environmental organisations increased dramatically. Though there is a long tradition of conservation and ecological consciousness in the Czech lands [Tickle and Vavroušek 1998: 122-124], by the 1980s the deteriorating state of the environment and its impact upon public health provoked a political response among intellectuals, conservationists, dissidents and the general public. Spontaneous public demonstrations over the levels of smog in north Bohemia, the formation of groups, such as Prague Mothers, and the politicisation of academics and conservationists within state organisations provided a fertile base for the development of environmental associations. In the months prior to the revolution the environmental issue had attracted an array of political dissidents who recognised its potential to further embarrass the embattled regime. The involvement of such activists served to link the nascent environmental movement to the larger clandestine dissident movement.

In the aftermath of the revolution a host of new organisations emerged. By early 1990 an estimated 800 groups existed [Šilhanová et al. 1994, 1996]. The new environmental NGOs consisted typically of young students who had been drawn to the environmental issue during the months prior to the Velvet Revolution via state organisations such as the Czechoslovak Union of Nature Conservationists (Český svaz ochránců prrírody CSOP), which had been established in 1979, or Brontosaurus, the conservation branch of the Socialist Youth Union [Tickle and Vavroušek 1998: 125, Waller 1989]. These new NGOs were small amorphous organisations that lacked cohesive internal structures. There was also a great deal of overlap between groups in terms of the campaign issues and the activists involved. NGOs were offered practical and financial assistance from a variety of external agencies, including the Swedish environmental organisation Secretariat on Acid Rain, philanthropic foundations such as USAID, the German Marshall Fund (committed 
to economic restructuring in eastern Europe), the British Know-How Fund, and from 1991 EU funding via the Phare Programme. NGOs received virtually no money from Czech citizens, nor did they seek to establish a fee-paying membership, preferring a handful of active members to passive supporters.

The organisation Hnuti Duha (Rainbow Movement), though it became one of the largest and most prominent NGOs, typified the nature of environmental protest at this time. ${ }^{3}$ Duha activists rejected a formal hierarchic organisational structure and the notion of non-active supporters, preferring activists to work independently on particular issues that were broadly defined by the 'centre of operations' in Brno. Though Duha has subsequently become one of the most politically prominent environmental lobbying groups, in the early 1990s it rejected a 'parliamentary' strategy and a hierarchic internal organisational structure in favour of direct action based on a global agenda and an amorphous cell-like internal structure.

Despite their global rather than national focus and a reluctance to embrace 'formal' politics, the larger Prague-based NGOs did enjoy close links with the newly established environmental agencies, and their opinions on policy were widely canvassed. This can be attributed largely to the collectivist attitude of the new dissident-based political elite. The first post-communist Czech environmental minister, Bedřich Moldan, and the new federal minister, Josef Vavroušek, had both been active in the Czechoslovak Academy of Sciences Ecological Section before 1989, and had been critical of government policy [Waller and Millard 1992: 170]. In their new governmental roles they sought close co-operation with the environmental NGOs and activists who they had campaigned alongside months before. This sentiment of co-operation and consensus found its most explicit institutional expression in the formation of the Green Parliament in early 1990. The objective of the Parliament was to create a discursive forum in which a wide array of environmental NGOs and officials could co-operate in the formation of a programme for environmental regeneration. The role and function of the Green Parliament were outlined in a document drawn up by the Czech Ministry of the Environment in 1990. The Parliament was described as 'an assembly of NGO representatives, to whom all the Ministry's significant plans shall be submitted for consultation and opinions' [Moldan 1990: 22]. The Parliament was to meet regularly at the Czech Ministry of the Environment in Prague, and although its recommendations were not prescribed as binding on the Ministry, there was a sense in which the new officials, lacking experience in policy-making and administration, were keen to consult interested parties. In the early months of the Green Parliament, the larger Prague-based groups such as Greenpeace, Děti Zemé (Children of the Earth), Hnutí Duha benefited most from the Green Parliament, and through it enjoyed close access to the policy process.

However, the seemingly ideal relationship between the various strands of the environmental sector concealed a number of underlying tensions. The greatest problem distracting the environmental movement until the mid-1990s was that the false unity of the environmental movement during the final months of communism had been fractured by the collapse of the old regime in November 1989. Mirroring wider political developments within Civic Forum, environmental activists had now to confront ideological differences

3) Information on Hnuti Duha was obtained from a series of interviews with Daniel Vondrouš between 1994-1999. Vondrouš has been a key figure in the organisation since its inception and is now its main lobbyist. 
and degrees of 'greenness' that had previously been eclipsed by their unifying opposition to Soviet-style communism. In addition, the environmental movement lost its upper-tier of activists as a result of political change. Many key figures at the time of the Velvet Revolution were now either engaged in government or on the fringes of formal political power (for example, Bedřich Moldan, Josef Vavroušek and Ivan Dejmal, who had been key figures within the movement, were now part of the new state environmental agencies). Although co-operation between the new elite and NGOs was close, their involvement and expertise within the protest movement was difficult to replace. Other former activists had retreated into academia, science or apolitical conservation; others simply left the political arena for the newly reclaimed private sphere, or indeed the new private sector.

Though certain environmental NGOs did exert a degree of influence on the new policy process via the Green Parliament and through close personal links with officials, the climate of co-operation and consensus was hindered by the fact that the NGOs needed to adjust to the changed political circumstances. Environmental protest had emerged as illegal or semi-legal clandestine opposition movements under authoritarian rule, enmeshed within a submerged and highly politicised 'parallel polis' [Havel 1985, Tismaneanu 1993: 153-174]. Environmental protest had occupied a uniquely political position during 1988-1989. An alliance of scientists, intellectuals, conservationists and sections of the general public had formed under the environmental banner. As a semi-legal activity apparently encouraged by the Communist Party, conservation had political potential as a means of lambasting the regime from a relatively safe quarter. The degradation of the natural environment also seemed to reflect and encapsulate all that was wrong with the political and economic system. In conjunction with other activists and dissidents (e.g. musicians, artists, peace campaigners) the clandestine environmental movement became a de facto opposition force within the closed and non-pluralistic Soviet-style political system. But after 1989, the environmental NGOs were required to enter the formal political sphere and co-operate and negotiate with the new democratic regime. They were being invited to sit round a table and help draw up a concrete policy framework; they needed to deal in facts and realistic strategies in order to help ameliorate the ecological degradation of the preceding decades. Though in the period just prior to the revolution environmentalists had deployed more overtly political tactics which included organising public meetings, leaking information to journalists and more open confrontation with the regime [Tickle and Vavroušek 1998: 127-129], the Czech communist leadership's authoritarian response and refusal to embrace the slightest liberalisation contrasted with events in Poland and Hungary and had not enabled environmentalists to gain the political experience that they now required. That the nascent NGOs lacked internal structures, cohesive ideological platforms on domestic issues, and appeared to shun the formal political policy process in favour of remaining enmeshed within a nascent civil society was a reflection of the circumstances in which they had emerged and operated during the final months of communist rule rather than a wholesale rejection of conventional Western-style activity.

One of the most fundamental considerations at this time was the question of what role NGOs should play in the new political order. Some environmentalists who had become politically involved during the last months of the communist regime now argued that the creation of new environmental agencies plus the ascendancy of the new proenvironment elite deemed the role of NGOs unnecessary. Others stressed the continued importance of environmental protest within democratic politics and were concerned by 
the apparent apathy of others with regard to critical issues such as nuclear energy that were being debated at this time. Those advocating a continued role for independent environmental NGOs were further divided over the nature of protest. Fearful of destabilising the new regime, some activists urged restraint and were unwilling to counter the notion of radical direct action within the new democratic system. Other more radical elements were reluctant to become enmeshed within formal politics at the national level and rejected conventional strategies in favour of more radical symbolic protest (e.g. the blockade of the proposed nuclear plant at Temelín). The need to adapt, to carve out a new role within post-communist politics and to alter patterns of internal organisation and strategy led to bitter rifts within the environmental movement which essentially paralysed effective mobilisation. Ideological disagreement over the nuclear energy issue and opposition to the Temelín plant in southern Bohemia led to the demise of the Green Parliament as NGOs fragmented, reformed, argued and, in many cases, folded.

There was something unusual in the fact that during the eighteen-month period after the revolution the environmental regeneration of the country was being propelled by the new ministers and state officials rather than by pressure from NGOs, who were distracted by internal ideological disputes and the need to adapt to the changed political context. Indeed, despite the ambitions of the Green Parliament, the rapidly constructed framework of environmental legislation was principally established by those within the new agencies with the help of certain activists and experts from the non-governmental green movement. Reluctant to work with each other, to widen their support base, or contemplate more mundane issues, the NGOs became increasingly detached from the formal policy process. In this sense the spirit of co-operation of the new political elite had come too early for NGOs who could not take advantage of the political climate. What was missing at this time was a sphere of environmental NGOs with the aptitude and expertise to co-operate at an elite level and to take advantage of the political climate of consensus. There was a sense in which the political elite were waiting for environmental NGOs to adapt and take up positions around the negotiating table. Unfortunately, elite-level political change towards the end of 1991 - the fragmentation of Civic Forum and the emergence of competitive political parties - ended this spirit of consensus, and by the time the NGOs had adapted and reformed their involvement was no longer sought.

\section{Political Marginalisation: 1992-1996}

That the fledgling Czech environmental movement was beset by ideological rifts after the revolution is hardly surprising. A polarisation between more moderate NGOs willing to engage with the political elite, and more radical elements that would pursue alternative strategies from within civil society typifies environmental politics across Europe [Young 1992]. However, what in fact occurred in the Czech case was that the radical protest and ideology of the immediate post-revolutionary period all but vanished. Although there emerged a core of Prague-based NGOs which gradually pursued a more moderate and increasingly state-focused strategy (e.g. Greenpeace, Duha and Déti Zemé), they were not co-opted within the political process and were in fact politically ostracised and castigated throughout the 1992-1996 period.

The role of environmental NGOs within post-communist politics had begun to change during the second half of 1991, largely as a result of the break-up of Civic Forum and the political demise of the dissident-based elite. However, it was the election of Václav Klaus and the centre-right coalition in June 1992 that contributed most to the po- 
litical marginalisation of environmental NGOs. As a broad-based movement, Civic Forum had tried to establish a political climate of consensus that was poignantly reflected in the Green Parliament initiative. The fragmentation of Civic Forum in 1991 and the subsequent emergence of western-style adversarial party politics profoundly altered the political framework in which environmental NGOs were to operate. The environmental issue became engulfed in the emerging ideological rift between forces on the political right advocating neo-liberal shock-therapy, rapid wealth creation and a deregulated society, and the non-communist centre-left who emphasised a more gradualist approach, civic rights and environmental protection [Jehlička and Kára 1994: 159]. Public concern over the environment had already begun to decline as the impact of economic restructuring took hold. The victory of Václav Klaus and his right-of-centre coalition in the June 1992 election signified the end of consensus politics and ushered in a climate of hedonistic individualism in which concern for the environment was suddenly politically unfashionable.

The political and economic reforms of the Klaus era had an impact on environmental protest in a number of ways. The most obvious impact was the political marginalisation of the environmental movement. Instead of dealing with an environmental minister and set of officials who had themselves been activists and who sought to establish a progressive policy framework through consultation with the environmental movement, NGOs had now to face a political elite whose main objective was to curtail the regulatory role of the state in order to ensure rapid economic liberalisation. As opponents of untempered, unregulated growth, environmental NGOs were immediately identified as political enemies. Further environmental regulation was viewed as an impediment to the economic agenda and dismissed as the 'icing on the cake' - something to be dealt with in the future once a prosperous market economy had been established [Klaus 1994]. In a move designed to further marginalise the environment as a political issue, the ministerial portfolio was handed to František Benda who, as a member of ODA (Občanská demokratická aliance - Civic Democratic Alliance), was politically weak within a coalition government dominated by ODS (Občanská demokratická strana - Civic Democratic Party). ${ }^{4}$ Far from there being any consultation between government and the environmental movement, Benda simply refused to meet NGOs and to set up any formal dialogue throughout his term of office. Such antipathy towards the environmental sector reached a nadir in early 1995 when three leading environmental NGOs were included on a security services' list of 'subversive organisations' which were to be the target of surveillance. The fact that the three environmental associations included on this list were committed to non-violent protest and to working within the democratic process, and that the other groups on the list were far-right neo-fascist organisations, provoked political outrage. President Havel intervened, as did a number of journalists and prominent figures in Czech society. As a result, two out of the three groups were eventually removed from the list [Fagin and Jehlicka 1998].

4) Initially, Benda remained loyal to Klaus and was keen to demonstrate his neo-liberal credentials by cutting funding to NGOs and to endorse the 'icing-on the cake' rhetoric of the prime minister However, as ODA's relationship with Prime Minister Klaus deteriorated Benda used the environment as a political tool: towards the end of his tenure he attempted to court environmental NGOs in a blatant attempt to humiliate the leadership. 
Not only were environmental NGOs politically marginalised and pilloried during this period, the environmental policy process that had been vigorously established in 1990 essentially ceased to exist. Apart from the odd amendment, virtually no new environmental laws were prepared or enacted between 1992 and 1996. Indeed, for much of this period there did not exist a long-term environmental plan or a set of future objectives. The prepared draft 'State Environmental Policy' was rejected by the government three times and was only finally passed in August 1995 after the withdrawal of any reference to sustainable development, a concept bitterly contested by Václav Klaus [Slocock 1996, Fagin and Jehlička 1998: 118]. The absence of a policy framework essentially removed the formal political stage on which the interaction between NGOs and the state occurred.

Not only environmental policy was halted during this period, the development of a legal and constitutional framework for associational activity in general also stagnated. The delay in establishing a coherent legal and fiscal framework for civil associations affected environmental NGOs. Though the Law on Associations had been included in the 1991 Civil Code and Constitution, subsequent legislation was required to clarify the legal position of foundations, civic associations, and non-profit organisations with regard to their basic right to exist and their fiscal rights with regard to tax exemption on donations. Under pressure from sections of the non-profit sector the Klaus government did finally enact the Law on Public Benefit Societies in 1995, though the act failed to clarify the legal position of civil associations such as environmental groups that do not ostensibly exist to provide public benefit, own property, or distribute grants. There was a certain irony in the fact that until recently environmental NGOs claimed the legal right to operate and raise funds on the strength of antiquated communist legislation. Klaus's oftenexpressed ideological antipathy towards such collectivist emblems as non-profit organisations, NGOs and civil associations explains the delay in establishing such a legal framework. ${ }^{5}$

The first dissident-led administration after 1990 had identified the importance of information relating to the environment being widely available [Moldan 1990]. It was recognised that environmental regeneration depended upon openness and co-operation based on the free flow of information between the new state agencies, NGOs, and the public. However, somewhat reminiscent of the later communist period, information relating to the environment became a political weapon in the adversarial and confrontational exchanges between the ministry and NGOs after 1992. It was thus not until 1997, after the political demise of both Klaus and Benda, that a freedom of information act relating to environmental information was enacted. ${ }^{6}$

The inertia of the Klaus government with regard to implementing the wide-ranging local government reform enshrined in the constitution also served to weaken the political capacity of local environmental NGOs. The success of the new Environmental Impact Assessment (EIA) process, which had been introduced during the 1990-1991 period but only came into effect after the 1992 election, depended on administrative reform and the

5) For an insight into Klaus's vision of civil society see [Havel, Klaus and Pithart 1996].

6) It was during the brief period of Martin Bursík's tenure at the Ministry of the Environment that information became freely available (on the Internet) and all files were opened and made available to NGOs (interview with Petr Štěpánek, former spokesperson for Martin Bursík, and Director of Public Relations at the Ministry). The Social Democratic government finally enacted a general Freedom of Information Act in May 1999. 
devolvement of power and responsibility to local government and planners. In the absence of such reform the process was thwarted by a combination of the lack of authority and prolonged tenure of communist officials reluctant to facilitate NGO and public involvement within the EIA process.

It was during the Klaus era that environmental NGOs began to experience a financial crisis that was to have a profound impact on their activities. The crisis was precipitated partly by changes in patterns of state funding on which environmental NGOs relied in the absence of sufficient levels of donations to NGOs from sections of Czech society (sections of the middle classes who typically fund environmental organisations elsewhere still lack sufficient levels of disposable income to make substantial donations), environmental NGOs have had to rely in the short term on the provision of state support and on donations from external agencies.

In recognition of the need for the state to support nascent civil associations, the first post-communist administration had established the State Fund for the Environment. This was to consist of the revenue from fines and licences paid by polluters. Half of the proceeds were to be made available, via the Ministry of Environment, to environmental NGOs and in particular to help establish an infrastructure within the sector. Thus organisations such as Zelený kruh (Green Circle), established to help co-ordinate the activities of NGOs and to strengthen the representation of environmental issues within the policy process, were to benefit. However, from 1992 onward, grants from the Ministry of the Environment were directed away from the more politically oriented NGOs and from projects seeking to strengthen the sector as a whole (e.g. information flow, resources, campaign expertise etc.) towards apolitical conservation projects. Thus Zelený kruh was denied funding for much of the period on the basis that it was not actually involved in conservation work. It has since been revealed that a sizeable amount of the funds supposedly available to NGOs from the State Fund for the Environment was actually directed towards private sector projects such as the building of incinerators, the environmental value of which is widely disputed. ${ }^{7}$ NGOs were also supposed to benefit from the Fond národniho majetku - Fund of National Property, which is essentially a small proportion of the revenue from privatisation. However, the distribution of this money was continually delayed throughout the Klaus period and was only allocated to NGOs in early 1999.

Although the environmental movement had begun to fragment shortly after the Velvet Revolution, the lack of adequate funding augmented divisions within the sector and effectively narrowed ideological diversity. As state grants were rationalised, NGOs became locked in a competitive struggle over the small grants that were still available. The political effect of such competition was a reluctance to co-operate with each other which further weakened the political efficacy of the environmental movement. But perhaps the most critical dimension of the financial crisis was that NGOs reacted to the political and economic climate and the apparent decline in support for the environment among the general public by rejecting their radical strategies and ideological platforms. The only visible occurrence of mild direct action was an annual blockade of the Temelín power plant. By 1996 Greenpeace no longer participated in the event and increasingly opposition to the nuclear energy issue was down-played in favour of less controversial issues or was approached from a less radical angle. For example, Duha worked with local

7) Interview with Petr Štěpánek, November 1998. 
groups opposing the building of nuclear waste storage sites in various areas across the country, but did not openly campaign against Temelín during this period. The NGOs did face a difficult task in campaigning against nuclear power as there had seemingly emerged a consensus which regarded nuclear energy as a 'clean' alternative to browncoal power plants. Though Déti Země and other NGOs did present alternative scenarios in their publications and reports, their lack of political access and inadequate resources made it difficult to stage an effective campaign. The only viable strategy seemed to be taking up local NIMBY campaigns against less controversial issues oriented around conservation.

The fact that the political and economic context encouraged environmental NGOs to adopt a more professional and less radical approach during this period can be viewed as a positive long-term development. In the sense that a stratum of NGOs willing to operate within the policy process was clearly missing in the earlier period, the emergence of less radical more state-oriented NGOs prepared to co-operate at an elite level seems an encouraging development. Yet the strategy bore little or no political dividend for NGOs during this period. Indeed, the three environmental NGOs included on the security services list of 'subversive groups' had all rejected direct action, and had sought to promote their professional image.

As state grants dwindled and the prospect of receiving donations from the Czech public and organisations was thwarted by the effects of economic restructuring, environmental NGOs became almost entirely reliant on the funding provided by external agencies. However, in light of the relative success of the political and economic transition in the Czech Republic, donations to Czech NGOs were rationalised and donors began to target their assistance elsewhere. The focus of attention began to shift from the relatively stable and prosperous Central Europe to areas of south-east Europe and parts of the former Yugoslavia. This was a period of recession across Europe and America, and international foundations and donors were forced to rationalise their support for Eastern European NGOs. Even Czech Greenpeace, which receives the bulk of its income from its international parent organisation and has never sought nor accepted state funding, also experienced funding difficulties as a result of financial constraints within the international organisation at this time. Unable to rely on substantial public donations, the Czech branch suffered more than Greenpeace branches elsewhere and the director was at one point forced to consider, against the wishes of Greenpeace International, corporate sponsorship. ${ }^{8}$ Levels of foreign donations to Czech NGOs have never recovered and the threat of further cuts and withdrawals continues to cast a shadow over the future of many environmental NGOs that remain dependent on external funding. By 1996 the American Ford Foundation, the Rockefeller Foundation, the US Peace Corps and USAID had completely withdrawn from the Czech Republic; C.S. Mott (US) had rationalised its assistance and EU money (through the PHARE programme) is increasingly being targeted towards projects that strengthen the economic infrastructure in view of possible Czech accession in the next decade.

By the mid-1990s environmental NGOs were essentially locked in a situation whereby their main sources of funding were in decline. There was a need to develop a base of fee-paying supporters from among Czech society. As noted above, this strategy

8) Interview with Hana Pernicová, Director of Greenpeace ČR, June 1995. 
was hindered by the fact that levels of disposable income amongst citizens inclined to support environmental NGOs were not high enough to enable sizeable donations, and also by the fact that the NGOs themselves were only gradually coming round to the idea of non-active fee-paying members. For instance, in 1995 Czech Greenpeace had barely 400 listed supporters, despite the commitment of the organisation internationally to accept passive fee-paying supporters [Rucht 1995]. Apart from the fact that most NGOs lacked the resources to invest in fund-raising expertise, there was (and remains) a distinct lack of fund-raising expertise in the country available to those NGOs willing to venture down this path. While the larger NGOs with international links (such as Greenpeace) were able to create a more professional image and develop their expertise during the 1992-1996 period, smaller groups were hindered by a lack of resources to acquire trained staff, accountants, legal advisers and even premises from which to operate.

The 1992-1996 period was the nadir for the environmental movement in the Czech Republic and a stark contrast to the immediate post-revolutionary period. In addition to the lack of resources and political marginalisation, the environmental movement now faced a public who were less sympathetic to its cause. Although environmental activists in the earlier period had made little attempt to court public support or establish a constituency of supporters from a wider section of the community, the climate of concern about pollution and its effects on health at the time of the Velvet Revolution created a positive backdrop to their activities [Ivan Dejmal in Lamper, Macháček a Petráček 1993: 9]. ${ }^{9}$ The impact of economic restructuring was now being felt, and public attention was focused on such 'material' issues as housing and employment. There was also little public support for radical tactics. The legacy of four decades of communist rule on political attitudes and values was a deferential political culture and a fear of radicalism. Environmentalists were seen by many as attempting to rock the political boat and thus a threat to democracy. The Klaus government undoubtedly pandered to this viewpoint by portraying environmentalists as enemies of reform.

If during the early period the environmental movement consisted of too many radical organisations and lacked more conventional groups willing to lobby parliament and focus on domestic issues, the legacy of the 1992-1996 period was precisely the reverse. By the end of 1995 the environmental NGOs that had survived had responded to the financial crisis and political exclusion by jettisoning radical strategies and ideological platforms. In fear of public reaction and government recrimination, the main NGOs were reluctant to contemplate any degree of direct action.

However, it has to be recognised that while the period 1992-1996 was generally a low point in terms of political influence and the development of the environmental movement in general, a small number of the larger NGOs who had links to large global organisations did manage to become more professional and began to focus on national issues and to lobbying parliament as a strategy. Though such attempts initially bore little fruit, by 1996 a small core of environmental NGOs (e.g. Greenpeace, Duha, Děti Zemé,

$\left.{ }^{9}\right)$ During 1990 the environment remained a key political issue. When one public opinion poll conducted by sociologists from Charles University asked respondents to name the most important issues for the new government to deal with, $83 \%$ named the environment as the most important issue [Jehlička and Kára 1994]. 
Society for Sustainable Living) were well informed, were prepared to work closely at an elite level, and were adept at producing well-researched reports and proposals. ${ }^{10}$

\section{A Political Renaissance?}

Just as the fragmentation of Civic Forum in 1991 and the change of government in June 1992 had had a direct impact on the environmental sector, so the loss of an overall majority for Klaus's ODS-led coalition in the 1996 election marked the first tentative steps towards a new era for the environmental movement. The replacement of František Benda as environmental minister with Jiří Skalický, a respected politician and fierce critic of Klaus, ushered in what might be termed a normalisation of relations between environmental NGOs and the ministry. The climate of outright hostility was replaced by a period of tentative co-operation between the more prominent Prague-based NGOs and a tactical politician. One of Skalický's first actions was to invite representatives of NGOs to a meeting at the ministry at which he expressed a desire for open dialogue. There was now also mounting pressure on the Czech Republic from the EU and the OECD to improve environmental regulation. The original framework of laws and instruments enacted after the Velvet Revolution had not been improved or extended, and future entry to both organisations depended on tighter and more extensive environmental regulation. In addition to opening up a new political opportunity structure for NGOs, the accession of Skalický also broke the legislative deadlock of the Benda years by drafting new legislation on waste. One of his first actions was to reduce energy subsidies, a policy that Greenpeace had been advocating for a considerable time. Whether out of a real commitment by Skalický to incorporate NGOs within the drafting of the legislation, or simply due to the fact that he became increasingly distracted by political tensions within the embattled coalition, Greenpeace was able to exert a significant influence over the new waste law, inserting a clause banning the import of goods containing PVC by the year 2001. This clause represented the most radical aspect of the legislation and extended the legislation beyond norms elsewhere in Europe. There was also contact between NGOs and the ministry on issues such as motorway development and energy policy.

As political events rapidly changed in the ensuing months, the political influence and position of environmental NGOs was to improve quite dramatically. The crisis which finally engulfed Klaus's embattled coalition towards the end of 1997 resulted in the formation of a caretaker government prior to the elections to be held in June 1998. Under the brief tenure of Martin Bursík as minister of the environment, NGOs enjoyed an unprecedented degree of influence and were granted unrestricted access to the process of beginning to draft and update existing environmental legislation. ${ }^{11}$ The temporary government

\footnotetext{
10) The role played by Greenpeace at the time of the floods in Moravia in early 1997 provides a good illustration of how far environmental NGOs had travelled towards becoming professional organisations. Greenpeace established the Phoenix Project urging the incorporation of solar energy within the re-building of all the destroyed villages. The project received wide-spread support from politicians, ministers, local politicians and notably the president (Interview with Hana Pernicová, former Director of Greenpeace ČR, November 1998).

11) In terms of actual new legislation this period produced very little. This is largely because Bursík's four month tenure made it impossible for him to draft new laws and get them through parliament - indeed, his first day in office was the last opportunity for the submission of draft legislation 150
} 
to which Bursík belonged was not bound by party discipline nor ideological rift (Bursík himself was politically and financially independent). His approach was to work with other ministries and to portray the environment as an integral part of all policy issues rather than trying to get more power for the Ministry of the Environment. This marked a significant departure from the approach of his predecessors (and even his successor, Miloš Kužvart) in the sense that, regardless of the political complexion of successive governments, there had always been a power battle between the environmental ministry, seen as insignificant and politically marginal, and other ministries such as industry. This erects a further barrier to the political influence of the environmental movement. Bursík's accession also marked the return of former dissidents to environmental politics. Involved with the human rights group HOS (Movement for Unjustly Pursued People), Bursík had forged links with environmental campaigners such as Ivan Dejmal and other prominent members of the clandestine Ecological Society in the 1980s. Some of those environmentalists were now involved with the Society for Sustainable Living and, not surprisingly, were invited to assist in up-dating environmental policy. Unfortunately, as part of a caretaker government, Bursík was in office for less than three months and was therefore unable to enact much new legislation (his third day in office was actually the last day for submitting policy to the parliament).

Since the election in June 1998 of a Social Democratic minority government, the political prominence of environmental NGOs established during the Bursík period has been maintained. There are clearly parallels with the early post-revolutionary period in the sense that a network of pro-environment politicians, lawyers and NGO activists has emerged, and there is once again an overlap between the NGO sector and state agencies and officials. The new minister, Miloš Kužvart, is a geologist and former member of the pre-1989 dissident environmental association, the Ecological Society. More recently he has been involved with the non-governmental sector, having worked for NROS (Nadace rozvoje občanské společnosti - Civil Society Development Foundation), the Czech organisation that distributes PHARE money to NGOs, and he is still a member of the highly influential Society for Sustainable Living. The Green Parliament has been re-established as a forum for consultation between the ministry and NGOs, and a new Legislative Group of environmental NGOs has also been established, which is sent draft copies of new laws and is asked to return comments and suggestions.

How has the environmental movement changed? The most visible dimension of the environmental movement is a core of Prague-based political NGOs (Greenpeace, Duha, Děti Země, Society for Sustainable Living). After four years in the political wilderness, these groups now enjoy a degree of influence and access to the policy process. Most of the prominent groups have now adopted a more conventional organisational structure and are directed by older (aged thirty plus) people who typically possess specialised highereducation qualifications in the natural sciences, management or the social sciences. Though this new management elite has been recruited quite recently in an attempt to inject more professionalism into NGOs, some of the current activists have remained within their organisations since the early 1990s. This marks a distinct contrast with the early 1990s when, after the older generation of activists had moved into government or else-

legislation to parliament. However, the foundations of a new policy agenda were laid during this brief period. 
where, the environmental movement consisted of a transient core of students under twenty-five.

In addition to political NGOs, the long established conservation groups such as ČSOP and Brontosaurus remain active. Although such groups became politicised at the time of the revolution they have largely moved away from political involvement in the post-communist period. ${ }^{12}$ Indeed, as restrictions were placed on the availability of state funding during the 1992-1996 period, ČSOP sought to emphasise its conservationist apolitical nature and, perhaps as a result, was the recipient of a sizeable proportion of the total amount of funding available to NGOs. The organisation has also received funding from the Czech National Savings Bank. ${ }^{13}$ Other NGOs that were once more radical and appeared to be following a political path have subsequently fallen into the ranks of the apolitical conservationists. For example, the environmental NGO Tereza, one of the most prominent organisations in the 1989-1991 period, established to promote environmental awareness among children, now prides itself on its apolitical position and seeks to distance itself from environmental issues within the political sphere (such as nuclear energy, transport etc.). The director of the organisation sees no contradiction in the recent decision to accept financial support form ČEZ (the Czech energy company) and Coca-Cola. It received payment from the latter for advising the multinational corporation on a green strategy for its advertising campaigns in the Czech Republic. ${ }^{14}$

Although Prague-based groups remain prominent, there exists a network of active local environmental NGOs has emerged focusing on specific local issues. An example of such activity is Prátelé prírody (Friends of Nature) in Ústí nad Labem which has mounted a campaign against the building of dams on the Elbe. The Prague-based NGOs have begun to work with such groups as part of the Environmental Impact Assessment (EIA) process, providing resources, advice and a link to the national political arena. Although even the larger local groups tend to rely on unpaid active volunteers, there is a recognition of the importance of public relations and successful media campaigns. ${ }^{15}$

There would also appear to be a renewed willingness by the larger NGOs to combine lobbying with carefully orchestrated direct action, reflecting the campaign strategies currently being pursued by environmental campaigners across Europe. After a period during which Czech Greenpeace and other NGOs were unsure about the value and appropriateness of publicity campaigns and were reluctant to use even mild direct action, more radical tactics directed at mobilising the public and humiliating polluters have recently been pursued: a Greenpeace campaign in 1997 against the Syntesia chemical plant in Pardubice was successful in winning widespread public support for the issue of tighter regulation of industrial effluent. Invited on a river 'tour', the public were offered foul smelling polluted water in wine glasses which had been discharged directly from the chemical plant.

This change of strategy is clearly linked to an apparent alteration in the attitude of the public towards the environment. When asked about environmental organisations in a

\footnotetext{
12) There are still radical elements within both these organisations, for example, the Brno branch of ČSOP.

13) Interview with Bedřich Moldan, 15 July, 1997.

14) Interview with Jana Ledvunová, Director of Tereza, 17 July, 1997.

15) Interview with Hana Konvalinková, Duha (Olomouc), 11 May, 1999. 
national opinion poll survey towards the end of $1996,87 \%$ of respondents said they were useful and important. ${ }^{16}$ More significantly, recent evidence suggests that the public may be better placed to offer financial support to NGOs. On a recent fund-raising campaign, Greenpeace more than tripled its donations from the public. For the first time some of the larger NGOs are now starting to keep lists of supporters and are targeting their fund raising accordingly. Apart from Greenpeace, other NGOs are still quite reluctant to accept subscription-paying passive members. Although low levels of disposable income amongst potential donors remains an obstacle to NGOs obtaining the sort of funding received by organisations elsewhere, the environmental movement clearly needs to consider the issue of fund-raising and to develop greater expertise.

The political circumstances surrounding the government's decision in May 1999 to continue with the Temelín nuclear power plant reveals a great deal about the changed relationship between NGOs and the government. It also provides an illustration of how the strategies of NGOs have also altered since the early 1990s. On one level the government's decision to continue subsidising the ill-fated scheme suggests that despite the more consensual and open political climate and the renewed influence of NGOs, the movement remains weak in the face of powerful political and economic interests. However, in conjunction with Greenpeace and other smaller NGOs, Duha orchestrated a highprofile campaign which coherently challenged the efficiency and economic rationale behind the pro-Temelín lobby. Indeed in the days before the decision was announced, Duha were actually briefing President Havel, who had decided to openly oppose the completion of the plant. ${ }^{17}$ Moreover, the NGO campaign, which focused almost entirely on the economic cost and inefficiencies involved if the government were to continue with the project, was arguably an appropriate response to the government's apparent determination to base the final decision on such considerations. The NGO campaign was well informed and highly professional.

However, NGOs are still adversely affected by inadequate levels of funding. Though apparently committed to working with NGOs, the new government has yet to alter the basis on which ministry funds are allocated. It has been declared that funding received by NGOs as part of the recently released proceeds from privatisation cannot be used to pay salaries but must be used for projects related to conservation. As a result, the more politically oriented organisations such as the Prague-based NGO Zelený kruh, which exists to strengthen the infrastructure of the environmental sector, cannot benefit.

Although smaller NGOs operating outside of Prague and other main cities are all affected by the absence of sustainable and sufficient levels of funding, it would appear that the specific political opportunity structure at the municipal level accounts for a great deal. Political attitudes within the locality is also a critical factor. For example, the České Budějovice-based NGO Jihočeské matky (South-Bohemian Mothers) has remained radical in terms of its campaigns and has not adopted a more formal and 'professional' internal organisational structure. The organisation is one of the few remaining NGOs in the Czech Republic to have actively opposed the completion of the Temelín power plant in Southern Bohemia throughout the past decade. The situative context in which the organisation has pursued its anti-Temelín campaign has been a major constraint. The local po-

16) The survey was conducted in November 1996 by the Institute for Public Opinion Research.

17) Interview with Vojtěch Kotecký, Hnuti Duha, 14 May, 1999. 
litical elite plus a substantial proportion of people in the area remain in favour of the completion of the Temelín plant largely for reasons of employment opportunities. Having failed in recent attempts to attract funding from any of the foreign foundations or from the state, Jihočeské matky now faces severe financial difficulties. ${ }^{18}$

The difficulties faced by Jihočeské matky can be contrasted with the experience of other NGOs operating at the local level. The Olomouc branch of Duha is similarly a small operation which depends almost entirely on volunteers from the local student community. However, reflecting developments within the Hnuti Duha generally, the Olomouc branch has become adept at holding press conferences and in dealing with the local administration. The local political context is also more conducive to NGO activity. The recently elected Social Democrat council campaigned against the previous centre-right government on a pro-environment agenda, and are keen to involve NGOs in the local policy process. The Duha campaign to reduce municipal waste has won them the support of the environmental department of the municipal authorities and in particular the local mayor. The NGO also benefits greatly from the fact that the town is heavily dominated by students from Palacký University, which provides a largely sympathetic background for their activities. Though funding remains an issue, the NGO benefits from a situation in which the local authority provides subsidised office space for which NGOs can apply. ${ }^{19}$

\section{Conclusion}

The fluctuating political efficacy of the environmental movement in the Czech Republic during the past decade can be attributed to a number of interlinked factors, most of which have been identified in the theoretical discourse on social movements in western democracies [Kriesi et al. 1995]. The political opportunity structure at both the national and local level and the political disposition of the incumbent government has clearly had an impact on the ability of the environmental movement to gain political influence. The election of a centre-right administration in 1992, and then a centre-left government in June 1998, had a direct impact on the political influence of the environmental movement. Though the ideological persuasion of a particular government clearly shapes the situative context in which environmental NGOs operate, the balance of power between ministries within that government also greatly affects political access. While the current centre-left administration contains a number of pro-environmental ministers, much rests on the ability of the environment minister, Kužvart, to overcome opposition from within his own minority government and party. The recent decision on the future of the Temelín nuclear plant illustrated that despite a pro-environmental core of younger ministers within the Social Democratic government, the old guard politicians who favour industrial interests over the environment are well placed (industry, transport) to overturn policy initiatives put forward by Kužvart.

The availability of resources for NGOs has long been recognised as a factor in the empowerment and mobilisation of interest associations within the political arena [Zald and McCarthy 1987]. In the case of funding NGOs in the Czech Republic, the resource issue is particularly significant in the sense that as a consequence of the communist legacy and subsequent economic restructuring, NGOs cannot rely on sufficient levels of

\footnotetext{
18) Interview with Jaroslava Brožová, November 1998. I am also grateful to Petr Jehlička for information obtained on this NGO as part of his as yet unpublished research.

19) Interview with Hana Konvalinková, Duha (Olomouc), 14 May, 1999. 
public donation, as is the case elsewhere in Europe. Though the recent experience of Greenpeace, discussed above, suggests that in fact the Czech public are now more inclined and able to support NGOs, levels of disposable income remain low and most NGOs lack the resources to invest in fund-raising. While it is assumed that in the long term this situation will alter, NGOs are currently dependent on limited state funding, on donations from foreign philanthropic organisations, and on aid from the EU. Such sources of funding are unsustainable and not the basis for the long-term development of NGOs. Though Czech NGOs have developed considerably over the past decade in terms of their internal organisation and interaction with the media and the public, smaller groups still lack basic resources and know-how. Post-communist societies lack the developed infrastructure of civil society that so benefits civil associations in more established democracies. This infrastructure is somewhat intangible: on a basic level it includes such practical assistance to NGOs as access to information (on other groups, new laws, foreign organisations), and to resources such as photocopiers, computers, and fax machines. Organisations such as the National Council for Voluntary Organisations (NCVO) in the UK provide training programmes ranging from effective public relations, fund-raising, and accounting practices, to legal advice. ${ }^{20}$ Though agencies and foundations exist in the Czech Republic offering such assistance (for example, the British Know-How Fund provides training as does the EU through the Phare Programme, and also the Soros-backed Open Society), the dissemination of resources and know-how is limited and often fails to extend to smaller organisations outside of Prague.

The funding and resource issue has had the greatest impact on the capacity of environmental NGOs. The political exclusion of the environmental movement during the Klaus period was exacerbated because of the lack of a robust and resourced civil society. The constraints on the development of such a western-style civil society include the legacy of four decades of communist rule which essentially destroyed the historic tradition of civic associations in the Czech lands, plus the impact of rapid and extensive economic restructuring since 1990, which has led to social fragmentation and displacement and does not lend itself to the development of cohesive and stable associations.

ADAM FAGIN is Lecturer in Politics at Queen Mary and Westfield College, University of London. He has published several articles on the environmental movement and the development of environmental capacity in the Czech Republic. Recent contributions include, (with Petr Jehlička) 'Sustainable Development in the Czech Republic: a doomed concept?', in S. Baker and P. Jehlicka (eds.) Dilemmas of Transition: The Environment, Economic Development and Democracy in East and Central Europe.

\section{References}

Dalton, R. J., M. Kuechler, W. Burklin 1990. "The Challenge of New Social Movements." Pp. 320 in Challenging the Political Order - New Social Movements in Western Democracies, ed. by R. J. Dalton and M. Kuechler. Cambridge: Polity Press.

Della Porta, D., M. Diani 1999. Social Movements: An Introduction. Oxford: Blackwell.

Eder, K. 1985. "The 'New Social Movements': Moral Crusades, Political Pressure Groups, or Social Movements?" Social Research 52: 869-901.

20) The NCVO receives financial support from the British Home Office as well as from charities and foundations. 
Fagin, A., P. Jehlička 1998. "Sustainable Development in the Czech Republic: A Doomed Process?" Pp. 113-128 in Dilemmas of Transition: The Environment, Democracy and Economic Reform in East Central Europe, ed. by S. Baker and P. Jehlička. London: Frank Cass.

Havel, V. et al. 1985. The Power of the Powerless. London: Hutchinson.

Havel, V., V. Klaus, P. Pithart 1996. "Civil Society after Communism: Rival Visions.” Journal of Democracy 7: 12-23.

Jehlička, P., J. Kára 1994. "Ups and Downs of Czech Environmental Awareness and Policy: Identifying Trends and Influences." Pp. 152-170 in Protecting the Periphery: Environmental Policy in Peripheral Regions of the EU, ed. by S. Baker, K. Milton and S. Yearley. London: Frank Cass.

Klaus, V. 1994. "The Pollution Problem of the Natural Environment of Human Existence." Lidové noviny, 14 February: 8.

Kriesi, H. et al. 1995. New Social Movement in Western Europe: A Comparative Analysis. London: UCL Press.

Lamper, I., J. Macháček, Z. Petráček 1993. "Nemáme právo poškozovat Zemi (We do not have the authority to gamble with the Earth)." Respekt, No. 1: 9.

Melucci, A. 1985. "The Symbolic Challenge of Contemporary Movements." Social Research 52: 789-816.

Moldan, Bedřich 1990. Životni prostředi České republiky (Environment of the Czech Republic). Prague: Academia.

Offe, Claus 1990. "Reflections on the Institutional Self-Transformation of Movement Politics: A Tentative Stage Model." Pp. 232-250 in Challenging the Political Order - New Social Movements in Western Democracies, ed. by R. J. Dalton and M. Kuechler. Cambridge: Polity Press.

Rucht, D. 1995. "Ecological Protest as Calculated Law-breaking: Greenpeace and Earth First! in Comparative Perspective." Pp. 66-89 in Green Politics Three, ed. by W. Rudig. Edinburgh: Edinburgh University Press.

Slocock, B. 1996. "The Paradoxes of Environmental Policy in Eastern Europe: The Dynamics of Policy-Making in the Czech Republic." Environmental Politics 5: 501-521.

Smelser, N. 1962. Theory of Collective Behaviour. New York: The Free Press.

Šilhanová, Hana et al. 1994. Basic Information about the Non-Profit Sector in the Czech Republic. Prague: NROS (Civil Society Development Foundation).

Šilhanová, Hana et al. 1996. Socially Oriented Non-Profit Organisations in the Czech Republic. Prague: NROS (Civil Society Development Foundation).

Tickle, A., Josef Vavroušek 1998. "Environmental Politics in the Former Czechoslovakia." Pp. 114-145 in Environment and Society in Eastern Europe, ed. by A. Tickle and Ian Welsh. Essex: Longman.

Tismaneanu, Vladimir 1993. Reinventing Politics: Eastern Europe form Stalin to Havel. New York: The Free Press.

Touraine, A. 1981. The Voice and the Eye: An Analysis of Social Movements. Cambridge: Cambridge University Press.

Touraine, A. 1988. "An Introduction to the Study of Social Movements." Social Research 52: 749788.

Waller, M. 1989. "The Ecology Issue in Eastern Europe: Protest and Movements." Journal of Communist Studies 5: 303-328.

Waller, M., F. Millard 1992. "Environmental Politics in Eastern Europe.” Environmental Politics 1: $159-185$

Young, S. 1992. “The Different Dimensions of Green Politics.” Environmental Politics 1: 9-43. 
Zald, M., J. D. McCarthy 1987. Social Movements in an Organizational Society. New Brunswick, NJ: Transaction Books. 